\title{
The Role of Central and Regional Government in the Regional Development of Albania
}

\author{
Ms. Alma Marku \\ European University of Tirana, Faculty of Economy, Tirana, Albania \\ Email: alma_marku@yahoo.com
}

\section{Doi:10.5901/mjss.2015.v6n2s2p49}

\begin{abstract}
Albania is a country in the Southeastern of Europe that has gone through many obstacles since its independence (1912) until the fall of communism regime or "the dictatorship of the proletariat" in 1991. After the fall of communism regime and the change of economy from a centralized one to an open economy, Albania is structuring its legal framework, institutions and agencies, policies, etc., in order to be a member of European Union. Due to its undertaken reforms and required ones from European Union, Albania is in a crossroad regarding the policies and institutional bodies of regional development. One of the latest reforms recently presented and approved in the Albanian Parliament is the new Territorial Reform, which has defined a new organization of the local government. Such reform has not yet been accompanied with a legal revision of respective existing laws. In this context, the lack of a legal framework which would define the roles and responsibilities of the local and government structures, makes things more difficult. Even though there is a financial instrument in place such as Regional Development Fund to eliminate disparities between regions, it is often object of mutual debate of the government and opposition because of the way of funding the projects. This paper tries to review the role of central and local/regional government in Albania with regards to regional development. Firstly, I will present the context of legal and institutional framework of the local and central government. Afterwards, I will try to explain the policy and financial framework of the regional development in Albania. In conclusion, Albania has to define by law the role and responsibilities of its bodies in local and regional levels. The new strategy on regional development should be more integrated with other sector and crosscutting strategies. Also development of capacity building of local and central government in the area of regional development is a key issue, follow the European integration process.
\end{abstract}

Keywords: regional development, local and central government, European integration.

\section{Introduction}

Albania is a country in the Southeastern of Europe that has gone through many obstacles since its independence (1912) until the fall of communism regime or "the dictatorship of the proletariat" in 1991. During this long-lasting regime (47 years) the Working Party was the only political governing party in the country ${ }^{1}$ and the private property was forbidden by the article 16 of the Constitution. After the fall of the communism the main challenges of the country was switching from the one party government to a series of democratic institution, and to open its planned economy to a democratic system of "free market".

After 23 years of democracy, Albania now is a member of NATO and has finally gained a candidate status in the European Integration process. This means that Albania has undertaken a series of reform in different areas. Regarding the reforms in the area of decentralization and division of power, governments have not done so much. If we study these processes we will see that in some cases they decentralize power to local level and in other cases they centralize some of the services that deliver the local government.

Nevertheless, in July 2000, the government of Albania approved two important laws: the territorial division of the country and the functioning of the local government. With the new government in place in June 2013 the law on territorial division was changed again by reducing the number of local units.

On the other hand there is not a clear definition on institutional responsibilities of regional development. Furthermore the lack of a law and integrated regional policies between central and local government make the picture darker by arising many question marks regarding the future of regions and the way they will be governed.

${ }^{1}$ Article 3, Law no. 5506, date 28.12.1976 "Constitution of People's Socialist Republic of Albania" 


\section{Brief History of Regional Development (Territorial Division)}

While studying closely the history of governance in Albania, we could encounter the consequences legacy left by the centralized government of dictatorship where the main principle of governance was centralization of the power and economy. This concentration of power led to the extinction or elimination of the concept of regional governance and thus "killed" the balance between the levels of the governance, which by the way suffers even today despite the reforms undertaken in the field of decentralization.

Until 1960 administrative division consisted of nine regions which included several districts and councils village advice. Under the ruling ideology of Marxism - Leninism and proletarian dictatorship after the 1960 reform, any previous form of regional and local government was gone. It was eventually eliminated the term "region" and state power was represented by Parliament which constitute the central government and the People's Councils that represented the local level.

After the democratic changes in the early ' 90 s, the reform of central and local government took place. The administrative division under the 1993 reform brought 12 prefectures, 36 districts and municipalities/communes which are the first level of local government. The territorial division of Albania done through Law no. 8653, dated 31.07.2000 divided the territory into two levels: counties and municipalities/communes. While the new Law on administrative-territorial division of local government units in the Republic of Albania divides the country into two units of local government, municipalities and counties.

\section{Legal and Institutional Framework}

\subsection{Central government level}

In relation to the hierarchy, Constitution is the highest law of the Republic of Albania. According to Constitution (Article 100), Council of Ministers defines the principal directions of general state policy. In order to do that, Council of Ministers adopts decision and instructions (Article 100/5).

The organization and functioning of the Council of Ministers, Prime Minister, Ministers etc., are regulated by the Law no. 9000, date 30.01.2003, "On the Organization and Functioning of the Council of Ministers". A directly elected organ of a local government unit may be dissolved or discharged by the Council of Ministers for serious violations of the Constitution or the laws (Article 115/1). Council of Ministers appoints a prefect as its representative in the counties of the territory (Article114). He or she supervises controls and coordinates the activity of the central institutions at the local level; directs the activities of state administrative structures, etc. ${ }^{2}$.

The minister, within principal directions of general state policy, directs the activities under his responsibility. He or she pursuant to its powers issues orders and instructions (Article 102/4). Inter-ministerial committees are consultative bodies of the Council of Ministers where policies and other executive issues and important activity are discussed. Regarding the regional policy, the Committee for Regional Development identifies all the issues of the regions. The establishment of this committee aims a more powerful support from the state budget for the regions/counties. It coordinates projects between regions and balances the distribution of financing between them.

\subsection{Local government}

\subsubsection{Territorial reform}

According to the Articles 108/1 of the Constitution, communes or municipalities and counties are the units of local governments. They perform all the duties of self-government, with exception of those that are given by the law to other units of local government. Communes and municipalities are the basic units of local government (article 108/3).

A county consists of several basic units of local government with traditional, economic and social ties and common interests. The county is the unit where regional policies are made and implemented and where they are harmonized with policies of the state ${ }^{3}$. The Article 113 of the Constitution regulates the constitutional powers of the communal, municipal and regional councils.

There are several laws that regulate the division of power and responsibilities between different levels of local

${ }^{2}$ Article 6 of the Law 8927, daten on 25.7.2002

${ }^{3}$ Article 110 of the Constitution 
government. A new political debate has appeared with the new territorial reform by the government since it reflects the units of the local government. In this regards, opposition is against this law with the main argument that it falls down under some provisions of the Constitution.

The territorial division of Albania is done through Law no. 115, dated on 31.07.2014 "On administrative-territorial division of local government units in the Republic of Albania". According to this law, local governance in our country is organized in two levels:

- Municipalities - 61; and,

- Counties $-12^{4}$.

Local government units enjoy certain rights such as the right of governance, property, the right of collecting revenues and making expenditures, the right of conducting economic activities, etc.

Table 1. Population according to regions. Source: INSTAT, Albania in figures 2013.

\begin{tabular}{|c|c|c|c|}
\hline Counties/Regions & Population & Area $\left(\mathbf{k m}^{2}\right)$ & Density $\left(\right.$ people $\left./ \mathbf{k m}^{2}\right)$ \\
\hline Berat & 145.236 & 1.798 & 81 \\
\hline Diber & 138.45 & 2.586 & 54 \\
\hline Durres & 275.471 & 766 & 360 \\
\hline Elbasan & 303.12 & 3.199 & 95 \\
\hline Fier & 318.102 & 1.89 & 168 \\
\hline Gjirokaster & 73.627 & 2.884 & 61 \\
\hline Korçe & 226.282 & 3.711 & 36 \\
\hline Kukes & 86.555 & 2.374 & 85 \\
\hline Lezhe & 138.349 & 1.62 & 62 \\
\hline Shkoder & 221.459 & 3.562 & 478 \\
\hline Tirana & 789.129 & 1.652 & 68 \\
\hline Vlore & 183.002 & 2.706 & 101 \\
\hline Total & $\mathbf{2 . 8 9 8 . 7 8 2}$ & $\mathbf{2 8 . 7 4 8}$ & \\
\hline
\end{tabular}

According to the definition of the Law no. 8652 dated on 31.07.2000, as amended (Chapter II, Article 5): "Commune" represents an administrative - territorial and community residents usually are in rural areas and in certain cases even in urban areas. Its subdivisions are villages and towns in special cases. Changes have to been done since the new law on territorial reform does not include this term or territorial division.

"Municipality" is an administrative - territorial and community residents are usually in urban areas and in certain cases also includes rural areas. Meanwhile, its subdivisions in urban areas called wards (established in territories with over 15000 inhabitants by the decision of the municipal council); when the municipality includes rural areas, subdivision called village (established in an area with over 200 inhabitants). A city is a residential center, which has an urban development perspective plan approved.

"County" is an administrative - territorial unit consisting of several communes and municipalities with geographic, traditional, economic, social and common interests. Its boundaries coincide with the boundaries of municipalities and communes that comprise it and its center is placed in one of the municipalities involved.

Representative bodies of local government are: municipalities/communes councils which are elected directly by the people; and counties councils are representative bodies of local governments. Under the provision of the law 8652, dated on 31.7.2000, the County has to prepare and implement the regional policies and harmonize their national policies at the regional level. The most important thing in the adoption of this law and its normative acts is switching the authority and responsibility for the functions of local authorities to counties. Transference of public property and financial independence are two important issues of local autonomy.

\subsubsection{Regional development}

There is no Law on Regional Development in Albania which will make a clear definition on the principles, objectives, division of power, tools and management of institutional framework for regional development. This law would complement

\footnotetext{
${ }^{4}$ Article 1

${ }^{5}$ Albania in Figures 2013, INSTAT, Tirana, 2014. Pg.11
} 
the legal framework of regional and local government in the Republic of Albania.

There was a draft law formulated during the implementation of the National strategy of Regional Development but it was not approved or sent for approval. Some of the objectives of this draft law were: promoting sustainable and balanced development between regions of Albania; strengthening the competitiveness of the economy throughout the country in accordance with the principles of sustainable development and evaluation of local and regional disparities; continuous improvement of quality of life in all regions of the country; continuous reduction of economic and social development disparities by promoting the integrated development of rural areas and a balanced development between regions of the country; revitalize disadvantaged areas highlighted (isolated from development; promoting inter-regional domestic and international, cross-border cooperation within the framework of Euro regions as well as participation in organizations and European structures, etc.

But what do we understand by the term "region"? In terms of this draft law, the region is the territorial integrity, which includes a number of territorial administrative local units of government. Meanwhile, regional development is a long process enhancement of sustainable social and economic development which will be achieved through the identification, stimulation and management of potential development of individual regions.

The draft law also provides the principles of regional development policy like: partnership and cooperation (between the public, private and civil and particularly between central state administrative bodies and local administrative bodies); solidarity and concentration (directed particularly towards additional support to areas that have lagged the national average); equal opportunities (the necessity of creating living conditions for all citizens in order to have equal opportunities to develop their potential); mutual fund and co-financing (through co-financing local budgets, national budget, donors, etc.); monitoring and evaluation (in order to increase the effectiveness, efficiency and impact on development); sustainability; information and transparency; and local autonomy.

\section{Policy Framework of Regional Development in Albania}

In November 2005 the Albanian government for the first time introduced a general government policy called Integrated Planning System, which was a set of operating principles to ensure the implementation of the government policy in a harmonized and efficient way.

Integrated Planning System had its focuses on 6 government processes focusing in the two main ones: National Strategy for Development and Integration (2007-2013) ${ }^{6}$, which is a document that defines the medium and long term objectives of the government and strategies for all sectors based on a national vision; Medium Term Budget Plan which requires each ministry to develop a 3-year plan for achieving program goals and policy objectives within the ministry's expenditure ceiling, determine the government's fiscal plan.

The National Strategy for Development and Integration 2007-2013 identified regional disparities that exist in the country a very serious problem, as well as the need for a new coherent and integrated regional policy. The vision of the government in the field of regional development was the development of sustainable and equilibrated regions of Albania, in general, focusing on the mountainous and remote areas with the aim of supporting the rapid development of the entire country.

In the draft of the new National Strategy for Development and Integration 2014-2020 the main challenge is to ensure a balanced development between regions of the country, and to increase the cohesion of the country's development in relation to other EU countries, through the consolidation of an effective system of regional planning and development.

The concrete steps in the field of Regional Development in Albania began in 2007. Ministry of Economy, Trade and Energy in the role of leading institution, had an extensive process of consultation with various interest groups which concluded with the crosscutting strategy of Regional Development 2007-2013. The document summarized policies, legal and institutional framework to be implemented, in order to fulfill the main objective of the government, that of sustainable growth and balanced socio- economic regions of Albania. Two main directions of this strategy were to reduce social and economic disparities across the country and create an efficient management framework for regional development. Unfortunately this strategy did some progress in the first direction and failed the second one since the law was not approved. The law would clear the role of each institutional structure to manage regional policies.

${ }^{6}$ NSDI 2014-2020 is not approved yet 


\section{Financial Framework of Regional Development}

The financial support of the central government for rural, local and regional government has always been a subject of debate between local and central government, government and opposition and so on. In 2005 the government of Albania introduced a financial mechanism in order to support the development of certain rural, local and regional areas called Competitive grants. This mechanism identified the priority projects to be financed by the central government. The focus of these projects was infrastructure, health, education, sewerage, etc.

Table 2. Financial support for the regions, period 1993-2010. Source: Albanian Development Fund

\begin{tabular}{|c|c|}
\hline Counties/Regions & Amount in milliard ALL \\
\hline Berat & 1.32 \\
\hline Diber & 2.59 \\
\hline Durres & 1.87 \\
\hline Elbasan & 2.22 \\
\hline Fier & 2.14 \\
\hline Gjirokaster & 1.82 \\
\hline Korce & 1.82 \\
\hline Kukes & 1.19 \\
\hline Lezhe & 1.88 \\
\hline Shkoder & 2.2 \\
\hline Tirane & 2.73 \\
\hline Vlore & 2.26 \\
\hline Total & 24.04 \\
\hline
\end{tabular}

But the implementation of this financial mechanism was seen as a support that government gave to those communities that were in the same political direction as the government. Furthermore, this mechanism has not made the region more competitive, so the government realized that the national budgetary policies should be harmonized with local budgetary policies.

To encourage the development of the smallest unit of the local government such as communes but also municipalities and up to the regional level the government decided to change its philosophy. In this frame, it is necessary to integrate the central level sectorial policies into the regional level. A new mechanism called the Regional Development Fund took the place of competitive grants scheme. The new philosophy introduced by this fund were the regional and local development, poverty reduction and avoiding the maximum fragmentation of the budget.

Another positive aspect of this instrument is the decision making process. There is a committee entitled the Committee on Regional Development, chaired by the Prime Minister, main ministers of the Government, the Chair of the Rectors' Conference, the Chair of the Association of Communes, the Chair of the Association of Counties and the Chair of the Association of Municipalities that approves the projects to be financed.

Table 3. Regional development fund allocations for the period 2010-2013. Source: Department of Strategy and Donor Coordination

\begin{tabular}{|c|c|}
\hline Year & Regional Development Fund in ALL \\
\hline 2010 & $8,893,428,786$ \\
\hline 2011 & $5,678,924,000$ \\
\hline 2012 & $5,618,683,000$ \\
\hline 2013 & $7,601,398,561$ \\
\hline
\end{tabular}

\section{Conclusions}

In June 2014 Albania granted the candidate status of EU. This means that there are a series of new implications for Albania. From an economic point of view, candidate status will encourage foreign investments in the country and as a result the units of the government should be prepared to make their locality or region more competitive. In order to do so they have to develop the capacity building in order to enhance their ability to identify and meet development challenges under the EU framework. 
The new Territorial Reform, approved lately (July 2014) should be complemented with sublegal acts and revision of the law on organization and functioning of the local government. Furthermore the approval of the law on regional development in Albania will complement the legal framework of the roles and responsibilities of the local and central government structures.

Another important aspect is the integration and coherence of the policies in the area of decentralization and regional development. The overall government policies on these fields should be integrated with those of the local and regional level. Beside the fact that the new framework of the National Strategy for Development and Integration and sector and crosscutting strategies for the period 2014-2020 are not approved yet, they should be in compliance with EU principles and recommendations.

Finally, the government should not be limited only by financing projects from regional development fund. It should help the remote and undeveloped areas with specialized projects in order to make them more competitive with other areas or regions.

\section{References}

Boldrin, M. and F. Canova (2001), "Inequality and Convergence: Reconsidering European Regional Policies", Economic Policy.

Bachtler, J and Michie, R., 1997. The Interim Evaluation of EU Regional Development Programmes: Experiences from Objective 2 Regions. Regional Studies.

Boldrin, M. and Canova, F., 2001. Inequality and Convergence in Europe's Regions: Reconsidering European Regional Policies. Economic Policy: A European Forum, (32), pp. 205-245.

European Commission and UNDP ISD Project, (2010), Towards a Revised Regional Development Policy Framework for 2010-2020.

Regional Policy Inforegio, (2010), Structural Funds Regulations 2007-2013

McClements, C, (2010), Cross-cutting strategy for regional development Albania, Review

European Commission, (2009), Albania 2009 progress report.

European Commission and UNDP ISD Project, (2010), Regional Disparities in Albania.

http://eur-lex.europa.eu (2006), Implementing Council Regulation (EC) No 1085/2006, Establishing an instrument for pre-accession assistance (IPA).

www.Publications.eu.int, (2004), European Union Regional Policy - working for the Regions.

http://www.dsdc.gov.al

http://www.dsdc.gov.al/dsdc/Regional_Development_Fund_485_2.php

Constitution of the Republic of Albania, Law no. 8417, date 21.10 .1998 (last changes approved with law no. 88/2012 date 18.09.2012)

Constitution of the People's Socialist Republic of Albania, Law no. 5506, date 28.12.1976, repealed

Law no. 115/2014, date 31.07.2014 on "Administrative territorial division of the local government units in the Republic of Albania"

Law no. 8653, date 31.07.2000 on "Administrative territorial division of the local government units in the Republic of Albania" repealed

Law no. 8652, date 31.07.2000 on "Organization and function of local government"

Law no. 9000, date 30.01 .2003 on "Organization and function of the Council of Ministers"

Law no. 8927, date 25.07.2002 on "Prefect"

INSTAT, Albania in figures 2013. Tirana 2014

National Strategy on Development and Integration 2007-2013

National Strategy on Development and Integration 2014-2020 (draft)

Decentralization and Local Government Strategy 2007

Regional Development Strategy 2007-2013 